\title{
3
}

\section{Archaeological Excavations on Batan Island}

\author{
Peter Bellwood, Atholl Anderson and Eusebio Dizon
}

This chapter identifies a major eruption of the Iraya volcano about 1500 years ago that buried many regions of central and northern Batan Island. It continues onwards to describe the layout of excavations and the stratigraphy revealed in the open sites of Sunget, Mahatao, Naidi, Payaman and Tayid, all buried beneath the Iraya ash. Excavations of post-eruption occupation layers in a number of caves and rockshelters are also described, and it is interesting to note that none of these caves or shelters produced any evidence for very ancient (pre-Neolithic) occupation. They seem to have been used mainly for occupation in the late prehistoric period of $i j a n g$ warfare.

Although slightly smaller than Itbayat Island in land area, Batan is the most fertile island in Batanes. It supports most of the population and has the most settlements, including the modern administrative centre of Basco with its airport and harbour. Dumb-bell shaped, the northern part of Batan is formed by the active Iraya volcano $(1009 \mathrm{~m})$, the southern by the extinct Matarem $(459 \mathrm{~m})$, with the narrow neck between formed by volcanic soils and occasional coastal outcrops of coral limestone (Fig. 3.1). Most of the agricultural activity on the island is focused today across this central neck, roughly from Basco to Mahatao (Fig. 3.2), and around the coastal flanks of Matarem. The northeastern and northern coastlines of the island are essentially uninhabited. Not surprisingly, the distribution of known archaeological sites follows the modern distribution of settlements and agriculture very closely indeed.

\section{Batan Island: Vulcanicity and archaeology}

Before describing the archaeology of Batan, it is necessary to examine the recent volcanic history of the island. The southern volcanic complex, Matarem, is no longer active, but many sites are buried under volcanic ash from a geologically very recent eruption of the northern volcano, Iraya. This ash blanket, dated to $c$.AD 500 (see below), provides a very useful minimum age in central Batan for the sealed archaeological assemblages from hill and ridge top sites, such as Sunget, Naidi, Payaman and Tayid, all discussed below.

A geological report on the island by Richard et al. (1986) was the first to indicate that archaeological sites were buried beneath deep layers of volcanic ash and lapilli derived from Iraya. This team collected charcoal of archaeological origin, radiocarbon dated to $2310 \pm 80 \mathrm{BP}$ (uncalibrated), from beneath ash and pumice layers at Naidi, near Basco. Wood beneath similar ash beds exposed on west Songsong Beach was also dated to $1700 \pm 210 \mathrm{BP}$. Wood from beneath another flow of coarse-grained basaltic andesite further east on Songsong Beach, closer to the volcano but above stratified ash beds 
stated to be equivalent to those at west Songsong Beach, was dated to $1480 \pm 50$ BP. These dates suggested, therefore, that a major ash and pumice-producing eruption of Iraya, affecting at least the western part of Songsong Bay, occurred at some time between 1700 and 1480 BP (uncalibrated).

So far, no major program of tephrochronological research has been carried out on Batan, but our archaeological results allow us to add more to the chronology obtained by Richard et al. 1986. The five locations excavated by us that have archaeological deposits buried under volcanic ash are shown in Fig. 3.1; these are Sunget, Naidi, Mahatao Town, Payaman and Tayid. Except for Mahatao, the ash beds appear to be in primary context, not secondarily redeposited. It appears that a major ash shower fell right across the central part of the island, being thickest in the west at Sunget and thinning towards the east at Tayid and Payaman, suggesting deposition during a season with a wind from the northeast. Only one catastrophic ash-yielding eruption occurred in each of the sites examined, but Naidi and Tayid both have evidence for a minor initial eruption that preceded the major one (Table 3.1).

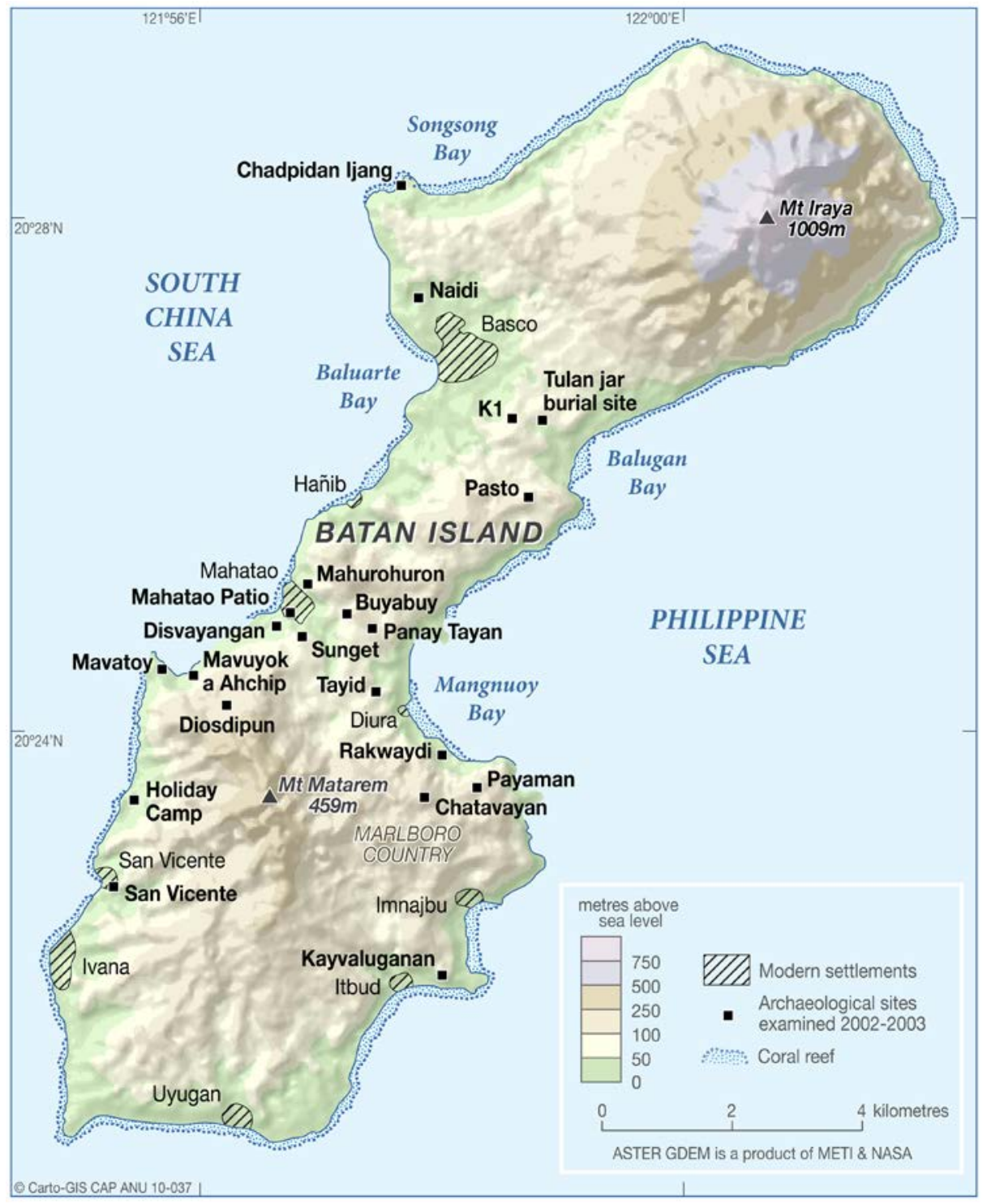

Figure 3.1. Sites investigated on Batan Island. K1, K6 and K41 are additional sites listed in Koomoto 1983 that have preeruption assemblages. 


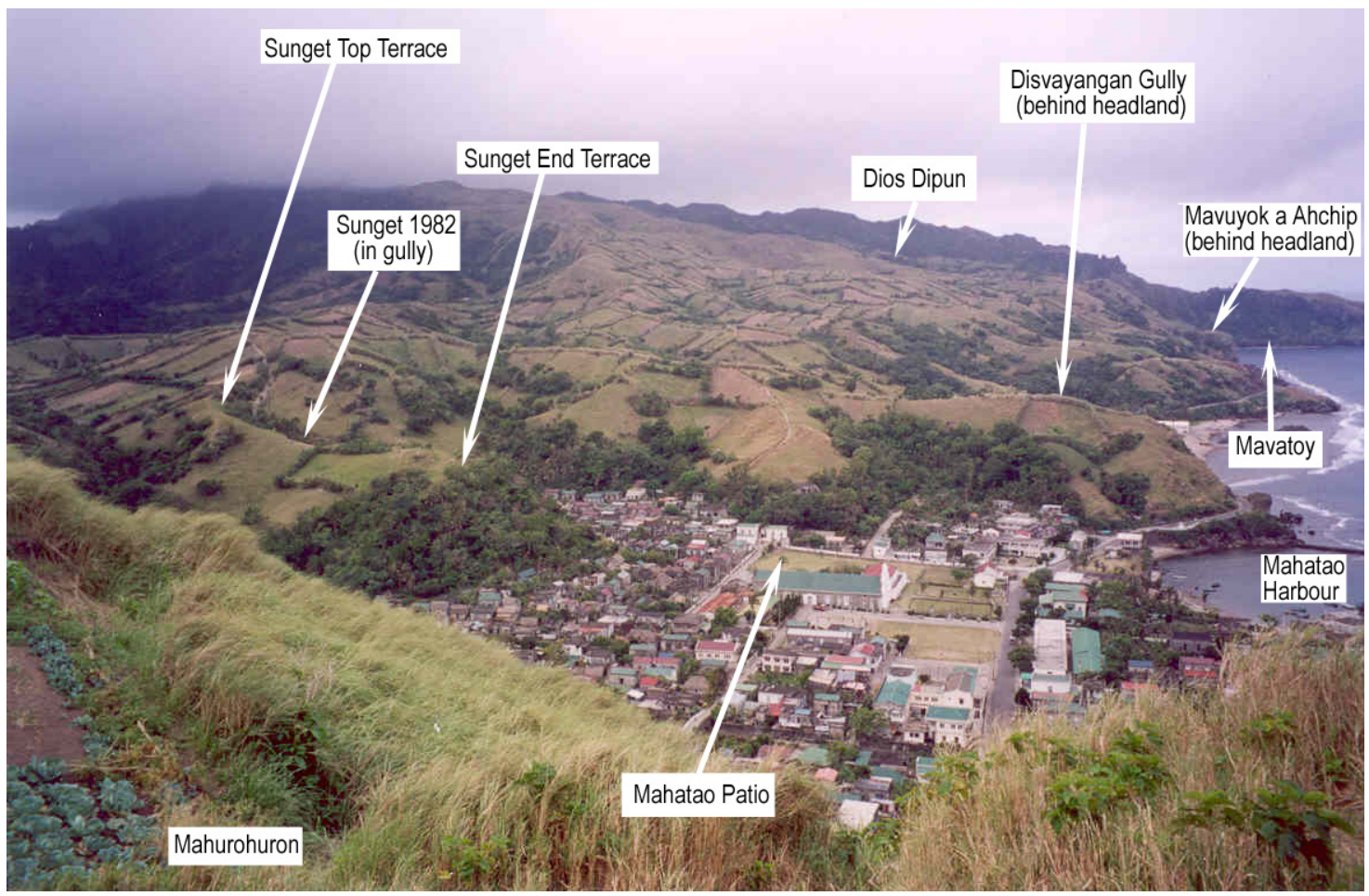

Figure 3.2. Mahatao and surroundings taken from Mahurohuron, showing the locations of the Sunget sites, Mahatao Patio, Disvayangan, Mavuyok a Ahchip (hidden behind headlands), Mavatoy, and Dios Dipun (approximate location only). The summit of Mt Matarem is under the cloud in the left background.

Source: Peter Bellwood.

Table 3.1. Ash deposits and uncalibrated $\mathrm{C} 14$ dates from locations in central Batan relevant for the date of the Iraya eruption (see Fig. 3.1 for locations). The dates in bold suggest that the major eruption occurred about 1500-1480 uncalibrated C14 years ago (C.AD 500).

\begin{tabular}{|c|c|c|c|c|c|c|}
\hline & \multicolumn{2}{|c|}{ Basco region } & \multicolumn{4}{|c|}{ Mahatao region } \\
\hline & $\begin{array}{l}\text { NAIDI } \\
\text { (this project) }\end{array}$ & \begin{tabular}{|l} 
SONGSONG BAY \\
(Richard et al. 1986)
\end{tabular} & $\begin{array}{l}\text { SUNGET } \\
\text { (this project) }\end{array}$ & $\begin{array}{l}\text { PAYAMAN } \\
\text { (this project) }\end{array}$ & $\begin{array}{l}\text { TAYID } \\
\text { (this project) }\end{array}$ & $\begin{array}{l}\text { MAHATAO } \\
\text { (this project) }\end{array}$ \\
\hline $\begin{array}{l}\text { Deposit above main ash } \\
\text { deposit }\end{array}$ & topsoil & $\begin{array}{l}\text { "nuée ardente" deposit } \\
\text { 10-30 m. thick }\end{array}$ & topsoil & topsoil & topsoil & topsoil \\
\hline $\begin{array}{l}\text { Dates above main ash deposit } \\
\text { (uncal. BP) }\end{array}$ & none & $1480 \pm 50$ & none & none & none & $\begin{array}{l}\text { Rakwaydi Phase } \\
\text { pottery }\end{array}$ \\
\hline Thickness of main ash deposit & 2 metres & none given & $0.7-1.2 \mathrm{~m}$ & $30 \mathrm{~cm}$ & $60 \mathrm{~cm}$ & $\begin{array}{l}\text { 5-6 m (in-washed } \\
\text { into former bay) }\end{array}$ \\
\hline $\begin{array}{l}\text { Culturally sterile, } \\
\text { intermediate topsoil }\end{array}$ & present & $?$ & not present & not present & present & $?$ \\
\hline Lower ash deposit & $20 \mathrm{~cm}$ & $?$ & not present & not present & $7 \mathrm{~cm}$ & $?$ \\
\hline Pre-ash C14 dates, uncal. BP & $\begin{array}{l}2620 \pm 30 \\
2310 \pm 80 \\
2240 \pm 140 \\
1590 \pm 210\end{array}$ & $\begin{array}{l}1700 \pm 210 \mathrm{BP} \text { (but } \\
\text { not stated to be of } \\
\text { archaeological origin) }\end{array}$ & $\begin{array}{l}2910 \pm 90 \\
2915 \pm 49 \\
2630 \pm 30 \\
2383 \pm 35 \\
2000 \pm 140\end{array}$ & $\begin{array}{l}1988 \pm 47 \\
1486 \pm 185\end{array}$ & $1842 \pm 215$ & $\begin{array}{l}2090 \pm 60 \\
1829 \pm 80\end{array}$ \\
\hline
\end{tabular}


Preliminary conclusions on Batan volcanic history can be summarised as follows, with respect to Table 3.1 (see Table 5.1 for further details of individual C14 dates):

1. Archaeological layers sealed beneath volcanic ash are widespread in central Batan. All radiocarbon indications are that these archaeological layers are older than 1486 radiocarbon years BP, this being the youngest terminus ante quem for the Iraya eruption.

2. The major ash fall apparently occurred between the two C14 dates of 1480 (Naidi - see above) and 1486 (Payaman) radiocarbon years BP, listed in Table 5.1. The correlation here seems almost too good to be true, since these two sites are $7 \mathrm{~km}$ apart. So perhaps we should be cautious and simply state that the major eruption of Iraya occurred $c .1500$ years ago. At Naidi and Tayid there was a minor pre-eruption, dating at Naidi after 1590 radiocarbon years BP, although the Naidi radiocarbon sample concerned was deficient in carbon and carbon dioxide and the date may be unreliable. In both cases, these thin preliminary ash falls were followed by short-lived topsoil formations.

This information on the recent volcanic history of Batan is important because it allows us to apportion the archaeology of the island into two separate chronological periods - before and after the volcanic eruption of $c .1500$ years ago. As we will see, the archaeological assemblages from these two chronological periods have some obvious differences, although no site actually spans the period of eruption itself, with continuous occupation below and above the ash (not surprisingly perhaps, given the extent and depth of landscape burial). Whether or not the eruption led to abandonment of the whole of Batan Island we do not know, but we did not see any deep Iraya ash deposits close to the southern coastline of Batan, or anywhere on neighbouring Sabtang Island. People presumably suffered less disruption in these locations.

\section{The Batan Island archaeological open sites}

\section{Sunget, Mahatao}

The importance of the Sunget site (Site 56 in Koomoto 1983: 55), on the limestone ridge that rises immediately behind the central part of Mahatao township in central Batan, was first indicated by a Japanese survey in 1982. They reported prolific quantities of red-slipped pottery, stone adzes and even a few items now known to be of Taiwan slate and nephrite (chapter 9) from the road cutting shown in Fig. 3.3. Our excavations at Sunget between 2002 and 2004 identified two areas of occupation located above this road cutting, about $55 \mathrm{~m}$ apart and separated by a steep slope. These were termed Sunget Top Terrace (Bellwood et al. 2003) and Sunget Main Terrace, the latter being located very close to and immediately above the road cutting. This is extremely important, since the materials found in the Main Terrace excavation are identical to those found by the Japanese team, and now we have a radiocarbon dated chronology. Minor excavation also took place on the Sunget End Terrace marked in Fig. 3.2, but only a very thin deposit of recent material, not discussed further, was found there. The Top Terrace excavations (2002-2004) totalled about 11 square metres, whereas the Main Terrace excavation was 2 by 2 metres, dug in 2004 (Fig. 3.3). 


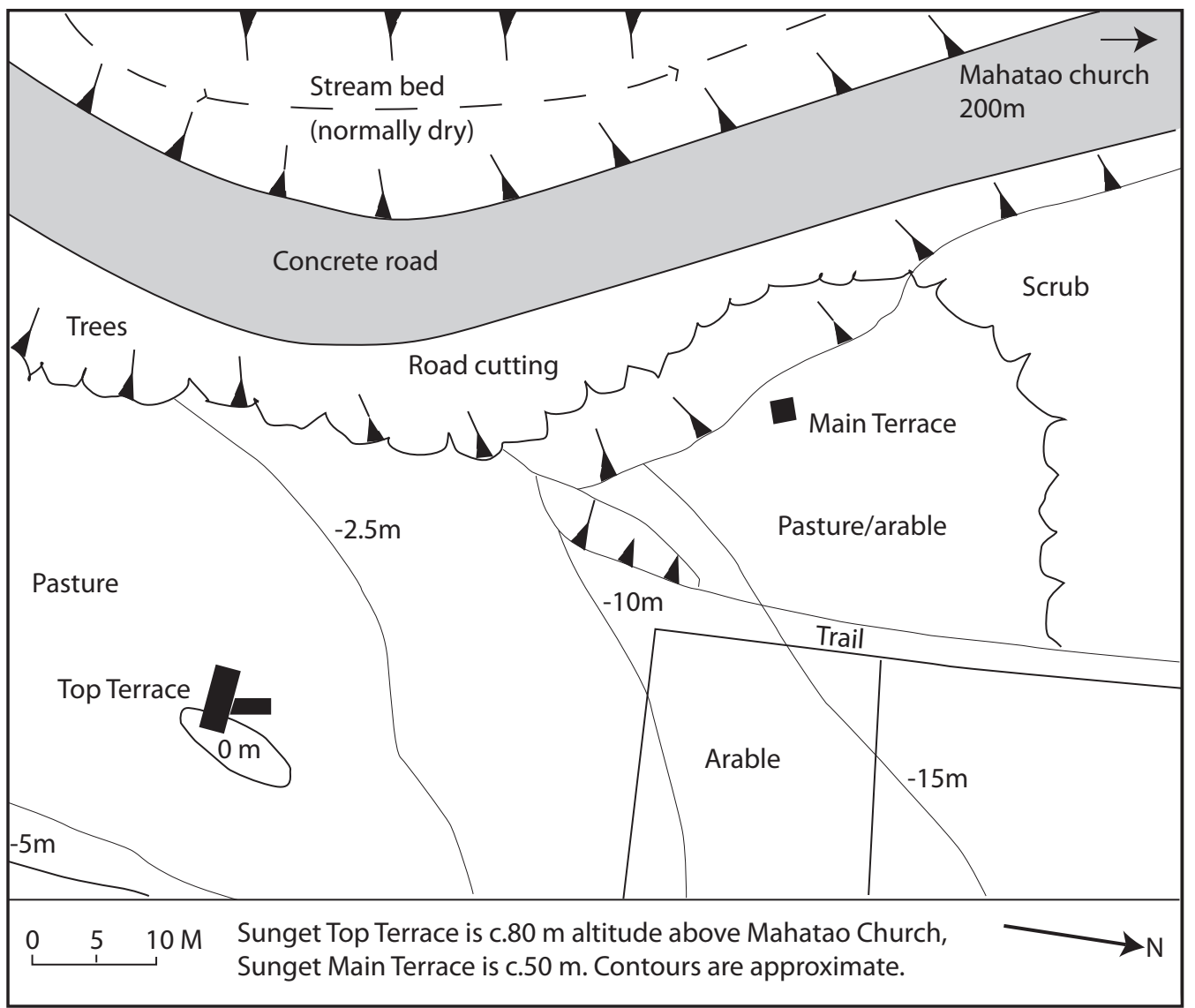

Figure 3.3. Plan of the Sunget Top and Main Terrace excavations, 2002-2004.

Source: Map preparation by ANU College of Asia and the Pacific, CartoGIS.

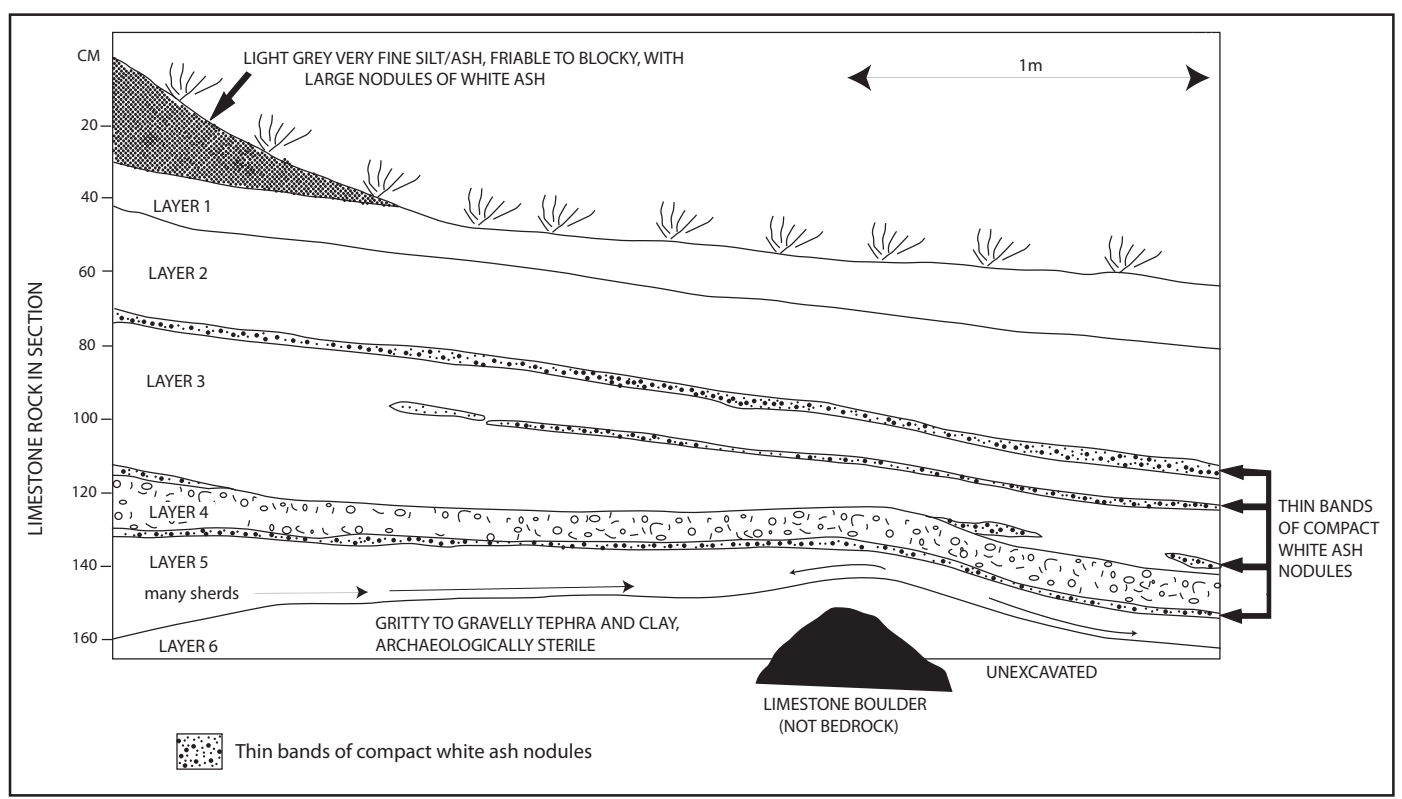

Figure 3.4. Section through the Sunget Top Terrace excavation, based on the southeastern wall of the 2002 trench. The archaeological deposit is layer 2.

Source: Lyn Schmidt. 
The cultural deposit in both locations occurred within a highly weathered topsoil buried around 1500 years ago by the Iraya eruption. The Top Terrace stratigraphy (Fig. 3.4) has been discussed and illustrated previously (Bellwood et al. 2003: 146-7), and that of the Main Terrace is essentially the same (Fig. 3.5). Here, the overlying ash is between $70 \mathrm{~cm}$ and $1 \mathrm{~m}$ thick since the ground surface slopes markedly, and there is the same layer of gravel-sized tephra at the base of the volcanic ash as in the Top Terrace, demonstrating deposition by the same volcanic event. The weathered dark brown clay loam topsoil that contains the archaeological assemblage, beneath the Main Terrace ash deposit, is about $30 \mathrm{~cm}$ thick. It grades downwards into an orange brown clay, as in the Top Terrace sequence. The Main Terrace archaeological layer is about $30-35 \mathrm{~cm}$ thick (Table 3.2).

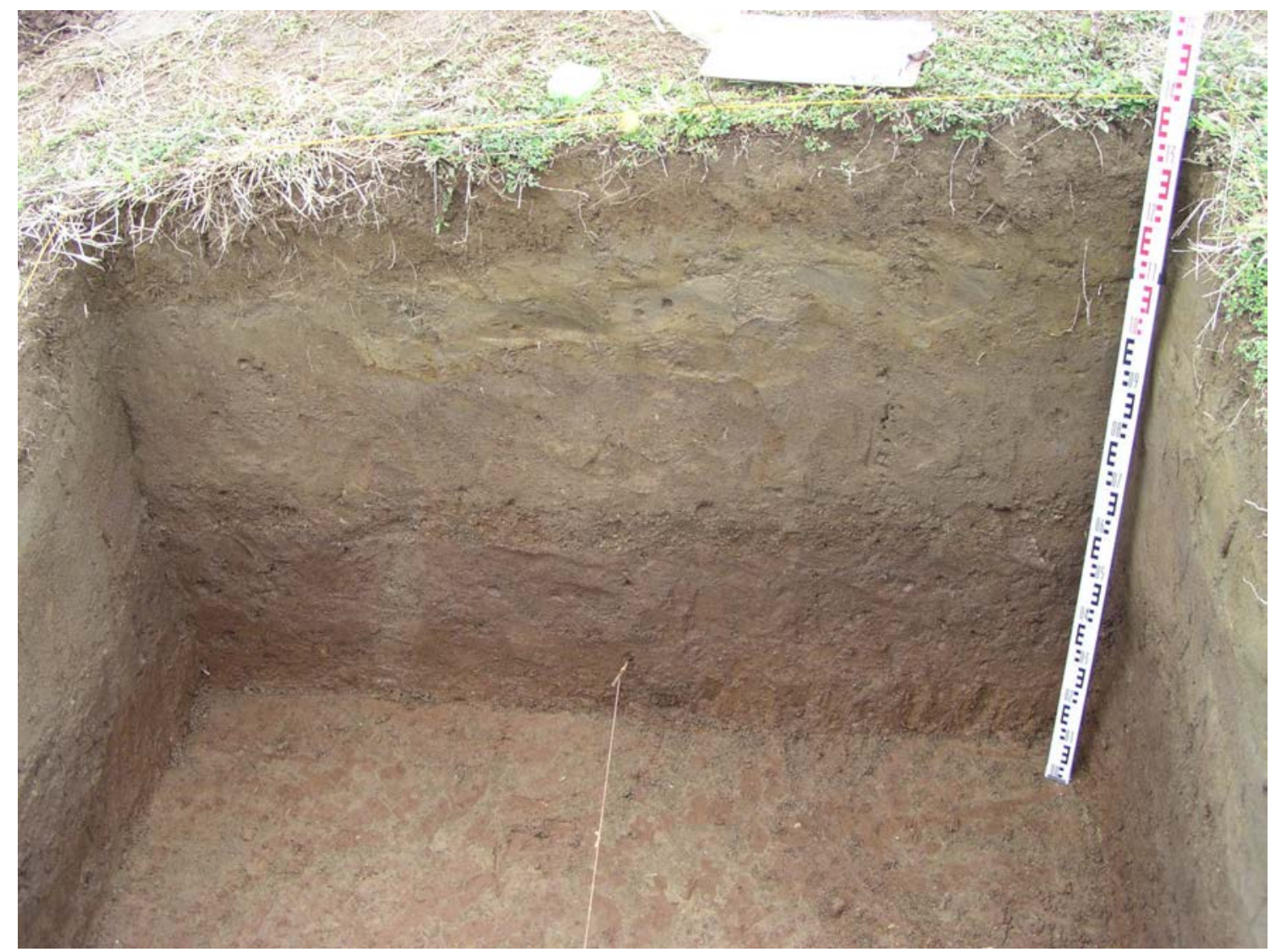

Figure 3.5. The Sunget Main Terrace excavation in 2004. The archaeological layer lies within the old topsoil buried beneath the yellowish mantle of volcanic ash and above the basal layer of orange clay.

Source: Peter Bellwood.

Table 3.2 shows the distribution of sherds for each area excavated at Sunget between 2002 and 2004, standardised in terms of density as the average number of sherds per square metre, within a $5 \mathrm{~cm}$ spit. These data reveal two interesting conclusions:

1. In the three linked Top Terrace excavations, sherds are densest against the limestone outcrop and fall off as one moves away from it. This suggests dumping of sherds against or from on top of the rock (Bellwood et al. 2003:147).

2. The Main Terrace has a single peak for the densest distribution, at $5-15 \mathrm{~cm}$ within the cultural layer. The occupation might, therefore, have been intensive and short-lived, with sherds subsequently dispersed by cultivation. In the Top Terrace excavation this peak was not so coherent, although there is a tendency for sherds to be most common towards the base of the old topsoil layer. 
Overall, the Main Terrace archaeological sequence is very similar to the Top Terrace sequence. The high degree of standardisation of the pottery confirms that we are dealing with one relatively short and contemporary period of intensive deposition in both locations. The main difference between the Top and Main Terrace depositional sequences is that the former lies over and against outcropping limestone, whereas the latter overlies continuous volcanic deposits to an augered depth of at least 5 metres. Indeed, there is another old topsoil beneath the Main Terrace, about 3.7 metres below the upper one that holds the archaeology, but this contained no visible traces of any human presence.

Table 3.2. Sherd counts per square metre of excavated area, by $5 \mathrm{~cm}$ spit, for the 2002, 2003 and 2004 excavations at Sunget.

\begin{tabular}{|c|c|c|c|c|c|c|c|}
\hline $\begin{array}{l}\text { Top Terrace Layer } \\
5,2002 \text { (away from } \\
\text { limestone) }\end{array}$ & $\begin{array}{l}\text { No. sherds } \\
\text { per square } \\
\text { metre }\end{array}$ & $\begin{array}{l}\text { Top Terrace Layer } \\
\text { 5, } 2003 \text { (against } \\
\text { limestone) }\end{array}$ & $\begin{array}{l}\text { No. sherds } \\
\text { per square } \\
\text { metre }\end{array}$ & $\begin{array}{l}\text { Top Terrace Layer } \\
\text { 5, } 2004 \text { (against } \\
\text { limestone) }\end{array}$ & $\begin{array}{l}\text { No. sherds } \\
\text { per square } \\
\text { metre }\end{array}$ & $\begin{array}{l}\text { Main } \\
\text { Terrace, } \\
\text { cultural } \\
\text { deposit }\end{array}$ & $\begin{array}{l}\text { No. sherds } \\
\text { per square } \\
\text { metre }\end{array}$ \\
\hline $0-5$ & 67 & $0-5$ & 177 & $0-5$ & 46 & $0-5$ & 50 \\
\hline $5-10$ & 62 & $5-10$ & 60 & $5-10$ & 45 & $5-10$ & 174 \\
\hline $10-15$ & 74 & $10-15$ & 108 & $10-15$ & 66 & $10-15$ & 187 \\
\hline $15-20$ & 66 & $15-20$ & 141 & $15-20$ & 48 & $15-20$ & 84 \\
\hline \multirow[t]{4}{*}{$20-30$ (10 cm spit) } & 156 & $20-25$ & 109 & $20-25$ & 134 & $20-25$ & 42 \\
\hline & & $25-30$ & 132 & $25-30$ & 90 & $25-30$ & 36 \\
\hline & & $30-35$ & $188^{*}$ & & & $30-35$ & 32 \\
\hline & & $35-40$ & $178^{*}$ & & & & \\
\hline
\end{tabular}

* Sherds between 30 and $40 \mathrm{~cm}$ depth in the 2003 excavation were found concentrated in a shallow basal channel against the limestone.

As far as the date of the Sunget assemblage is concerned, we now have two almost identical calibrated AMS dates, on food residues inside potsherds, that lie between 3200 and 2950 radiocarbon years BP (Table 5.1 - note that ANU 11817 and Wk 14640 are from two different laboratories, a circumstance that supports their combined validity). OZH 776, on an external resin glaze on a sherd, is far older than expected and can perhaps be explained by the use of fossil resin as a surface glazing material. Sample ANU 11693 (c.2800 cal. BP) perhaps refers to slightly later activity on the site since it is from a concentration of charcoal, possibly derived from a former hearth. But the much younger dates Wk 15649 and ANU 11707, both late first millennium BC, are on scattered small fragments of charcoal that presumably derive from some form of agricultural activity - perhaps clearance followed by burning and later digging stick disturbance - long after the archaeological site had gone out of regular use.

The significance of the Sunget assemblage is that it represents a short-lived phase of occupation on the ridge above the current site of Mahatao town, early in the sequence of human occupation of Batan (c.1000 BC) and at a time when Mahatao Bay was still occupied by the sea. The eruption of $c$.AD 500 filled in the bay and buried the Sunget sites, which by that time had long been abandoned and were under cultivation. Since the eruption took place there has been absolutely no occupation of this ridge, except for agricultural activities, so the rich materials collected by the Japanese team in 1982 can only date from the period of Top and Main Terrace occupation, between 1200 and $800 \mathrm{BC}$. This is most significant because of the occurrence of items of Taiwan slate and nephrite in the assemblage - Sunget has yielded the oldest item of Taiwan nephrite found so far in Batanes (chapter 9; Fig. 9.2). 


\section{Investigations in Mahatao}

When Mahatao was visited by Dizon and Bellwood in 2001, the Patio, an open grassy area next to the church, was found to be covered in pottery, much of it red-slipped like that reported from Sunget by the Kumamoto team. Unfortunately, two small excavations in 2002, near the locations of auger holes M1 and M2 in Fig. 3.6, showed that the whole area had been disturbed by grading and well-digging. The results of these excavations are not detailed here, and it is likely that much of the pottery had washed down from Sunget through a narrow valley that opens near the rear of the Patio.

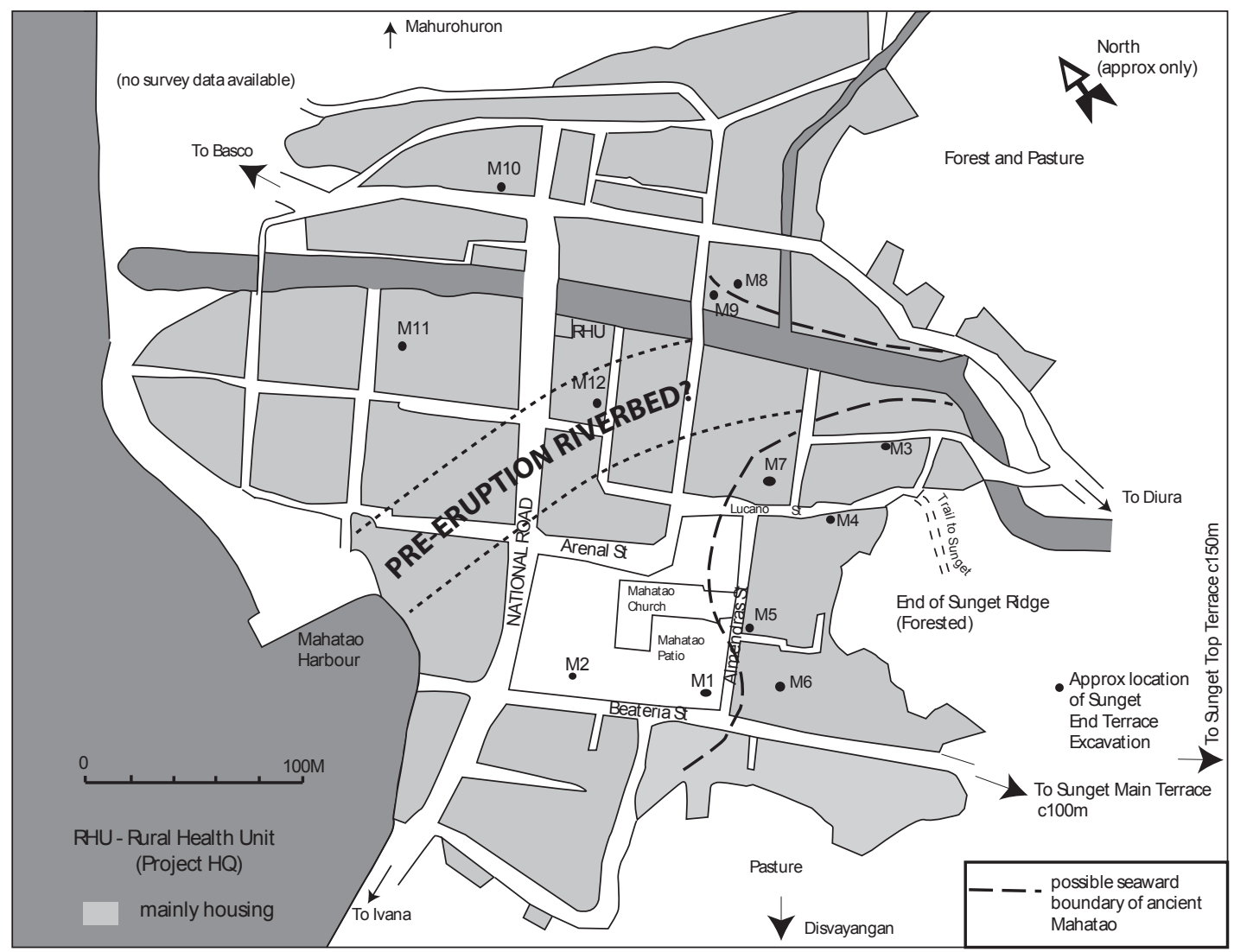

Figure 3.6. Plan of Mahatao showing auger hole locations (M1, M2, M5, M6, M7), Mahatao Septic Tank site (M3), another find-place of pottery beneath volcanic ash (M4), and the find place (M8) of the untanged and polished basalt adze $19 \mathrm{~cm}$ long with a reversed triangular cross-section, shown in Fig. 8.5B.

Source: Map preparation by ANU College of Asia and the Pacific, CartoGIS.

In 2003, several more auger holes were drilled in gardens below the end of Sunget Ridge in a hunt for the source of a quantity of circle-stamped pottery of Sunget type, with lots of large marine shells, that team member Shawna Yang found one day dumped alongside one of the Mahatao basketball courts near the church. We knew this material had to come from a limestone soil that preserved shell in good condition. The Sunget Ridge is limestone, and since all households in Mahatao have septic tank pits dug to a depth of about 2 metres in which artefacts are commonly found, we decided to drill a few auger holes in gardens below the end of the ridge since the most likely source must lie somewhere there. None of these auger holes, however, produced such a source, and no one could recall where the basketball court sherds came from. 


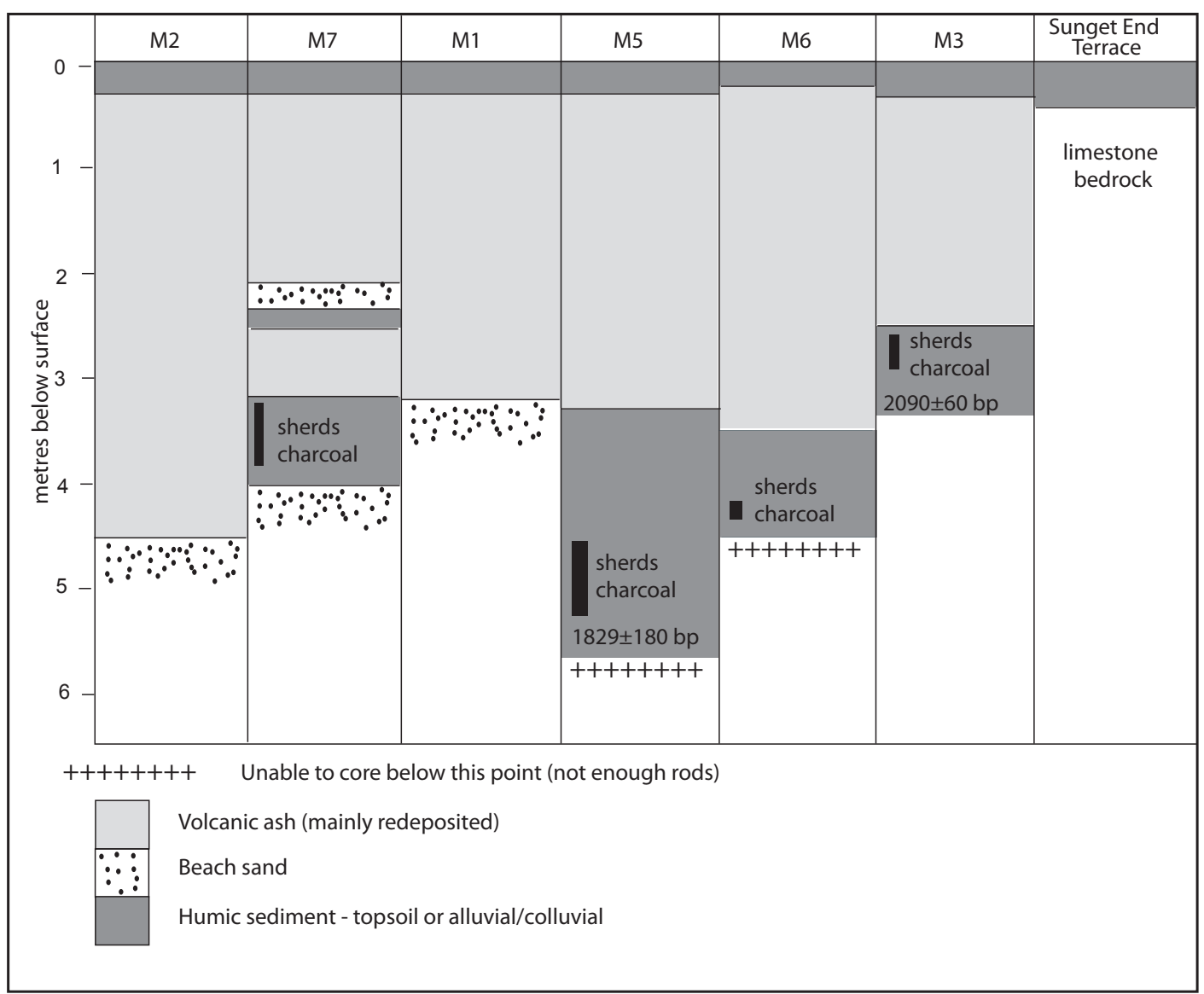

Figure 3.7. Layers revealed in the Mahatao auger holes indicated in Fig. 3.6.

Source: ANU College of Asia and the Pacic, CartoGIS.

Despite this, the auger holes do give interesting information about the disposition of the preeruption coastline beneath Mahatao, summarised in Figs 3.6 and 3.7. Locations M3, M5, M6 and M7 have sherds and charcoal stratified in humic dark soil layers (old topsoils) beneath redeposited Iraya volcanic ash, that was presumably washed down from Sunget Ridge after the eruption around 1500 years ago. The M3 (Mahatao Septic Tank) pottery was recovered in 2002 and is dated to $2090 \pm 60$ radiocarbon years BP (ANU 11710). Locations M5, M6 and M7 also have old topsoils with sherds and charcoal beneath the ash. Unfortunately, augering in M5 and M6 had to stop before we could get below the artefact-bearing layer since we only had 4 onemetre auger rods with us in 2003 (M5 was augered to 6 metres since we were able to climb down two metres into an abandoned septic tank pit). However, we were able to establish that locations M1 and M2 (both augered in 2002) and M7 (augered in 2003) finished in clean beach sand.

These data indicate that, before the Iraya eruption, the flat embayment upon which modern Mahatao township stands did not exist, except for a narrow strip of coastal soil around the head of the bay, just above the shoreline delineated by a partly guesswork dotted line in Fig. 3.6. The eruption itself presumably helped to fill in the bay, not just by direct ash deposition but also by the subsequent in-washing of huge amounts of ash from hinterland valleys and slopes. Before the eruption, the main river of Mahatao must have debouched into the harbour between locations M3 and M8. It still flowed through the centre of the village, apparently running just north of the church, into the modern harbour until the 1940s, when it was canalised within its still-existing concrete retaining walls (William Agsunod, pers. comm.). 
Given this reconstruction of ancient Mahatao it is no surprise that so many archaeological materials should have been found on Sunget Ridge, where no houses exist today. In the preeruption period, the population would have been restricted to a narrow coastline and people must have moved up to satellite hamlets on Sunget Ridge itself, into areas used today only for pasture and cropping. This is an important observation for the landscapes entered by Neolithic settlers in the Philippines generally, since it implies they would have been much steeper with much less low-lying flat land than one sees today. A similar presence of steep coastlines and a corresponding absence of coastal flats has also been postulated for Ilocos Norte on Luzon by Bellwood et al. (2008), as a result of research near Laoag and Paoay. Neolithic farmers in the Philippines would have had difficulty finding good flat agricultural land close to the sea at this time, just after postglacial sea level reached its mid-Holocene maximum, as they would in all of the Wallacean regions of Island Southeast Asia not flanked by shallow offshore continental shelves (Bellwood 2011b). This doubtless offered a situation remarkably different from the vast coastal and alluvial plains that support the densest modern populations of China and Southeast Asia, all mainly a result of Neolithic to modern sedimentation.

\section{Naidi}

The Naidi site is exposed beneath tephra as a single continuous archaeological layer about $20 \mathrm{~cm}$ thick, in a road cutting 63 metres above sea level between Basco and Songsong Beach (Bellwood et al. 2003: Fig. 7). The main exposure is on the west (upper) side, where the cutting is about 150 $\mathrm{m}$ long. The stratigraphy is very consistent along the section and there is no sign of any cultural material in layers beneath or above the cultural layer itself, with the exception of some unslipped sherds in the modern topsoil. The volcanic ash deposits above the archaeology here extend to a depth of $2.4 \mathrm{~m}$, with intervening thin topsoil formation at about $2.1 \mathrm{~m}$ (see Table 3.1). Two small excavations into the side of the road cutting in 2002 yielded quite abundant pottery beneath the ash. As detailed in Table 3.1, three C14 dates from different locations (and thus not in a stratified series) are now available for this deposit, together with that of $2310 \pm 80$ radiocarbon years BP from Richard et al. (1986). The calibrated range of these dates is from $835 \mathrm{BC}$ to $\mathrm{AD} 900-$ in actuality a much wider range that can be accommodated by such a shallow archaeological deposit. The main concentration of dates points to the late first millennium BC for the Naidi assemblage.

\section{Payaman}

The Payaman site was discovered by chance when we were searching for the source of the Mahatao basketball court pottery referred to above, which some of the Mahatao municipal labourers believed to be from near this locality. The archaeological layer had been disturbed by the grading of the Mahatao municipal dump, located high inland on the edge of Marlboro Country, and redslipped sherds were strewn thickly around. Augering quickly located an undisturbed area near the perimeter fence of the dump, and a 2 by $1 \mathrm{~m}$ square was dug in 2003 . The stratigraphy is very simple (Fig. 3.8, and see Bellwood et al. 2003, Fig. 8), with culturally sterile topsoil and subsoil (layer 1) over primary volcanic ash (layer 2), here much thinner than at Sunget, in turn over cultural layer 3, an old volcanic topsoil. Within layer 3, sherds were remarkably numerous, but extremely small and eroded, and concentrated heavily between 10 and $25 \mathrm{~cm}$ below the surface of the layer. This layer has two C14 dates of $1988 \pm 47$ (Wk 13092) and $1486 \pm 185$ radiocarbon years BP (ANU 12068). Like Sunget, Payaman was deserted and probably under cultivation when the Iraya ash fall occurred. 


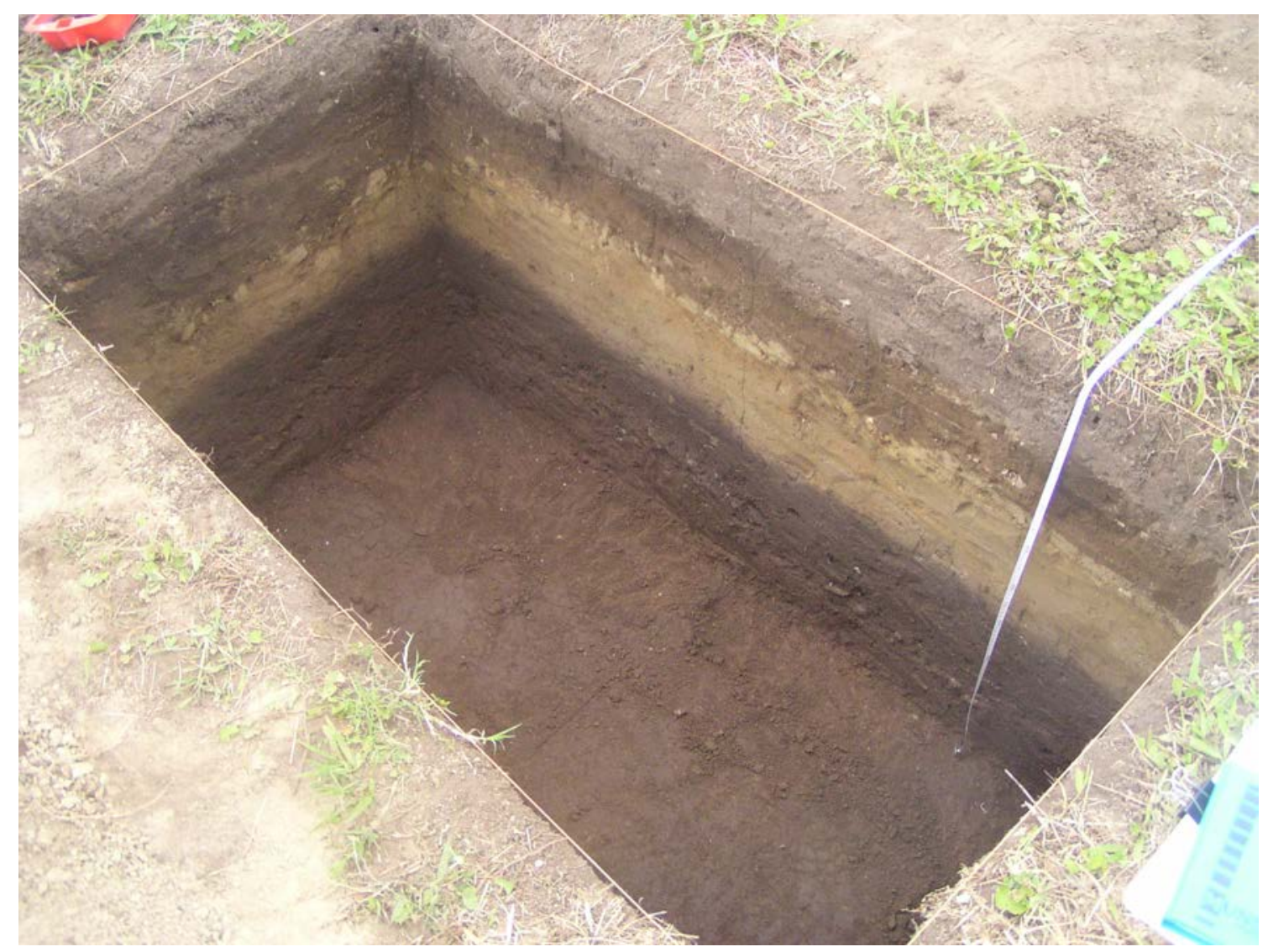

Figure 3.8. The stratigraphy of the Payaman site, Batan Island.

Source: Peter Bellwood.

\section{Tayid}

The Tayid site was originally reported by Koomoto (1983, Site 49), who noted the presence of two archaeological layers separated by "silt" layers, now known to be volcanic ash. The site is exposed in a road cutting, and two small "windows" were dug into the cutting in 2003 to check the stratigraphy. This consisted of 6 layers, as follows:

Layer 1: topsoil and redeposited volcanic ash, $50 \mathrm{~cm}$ thick;

Layer 2: Primary volcanic ash, $60 \mathrm{~cm}$ thick;

Layer 3: Old topsoil, $10 \mathrm{~cm}$ thick, with a small number of featureless plain body sherds;

Layer 4: Primary volcanic ash, $7 \mathrm{~cm}$ thick;

Layer 5: Old topsoil, $20 \mathrm{~cm}$ thick, containing the bulk of the archaeological sherds and with a posthole visible in section, dated $1842 \pm 215$ radiocarbon years BP (Table 5.1);

Layer 6: Culturally sterile red brown clay.

About 50 metres away from the two test pits, also visible in the road cutting in 2003, lies part of a volcanic stone pavement about 2.5 metres long that underlies the ash layer 4 . This suggests that the site may contain domestic architecture. Koomoto (1983: 49-52) also noted the finding somewhere on the site of a broken baked clay casting mould for a cupreous spearhead (Fig. 8.11 
G). A similar baked clay mould found at Savidug on Sabtang Island in 2006 (Fig. 8.11 F) would appear to date between 2500 and 2000 BP. Without further information we cannot know if the Tayid mould came from layer 3 or layer 5 , or if it was just a surface find.

\section{Batan Island cave and rockshelter excavations}

\section{Mavuyok a Ahchip}

The geomorphological location of Mavuyok a Ahchip, excavated in 2002, is in the seaward wall of a dormant and highly weathered andesitic crater that lies on the northwestern flank of the Matarem volcanic complex, on the western coast of Batan Island. The western (seaward) wall of the crater has been eroded down to about $50 \mathrm{~m}$ in height above sea level, and the modern road runs along the top of it. Four sea caves have been cut into this crater wall, presumably where preexisting lava tubes or faults offered lines of weakness. Two of these caves run side-by-side right through the crater wall from the sea into the inner crater valley (Fig. 3.9). The smaller, called Mavuyok a Ahchip by local people, is high and dry at its inland mouth, where it contained an archaeological deposit that covered an area of about 4 by 2 metres in total, flanked by a deep erosion gully. The wall of this erosion gully revealed dense sherdage down to a depth of about 95 $\mathrm{cm}$ below the surface.

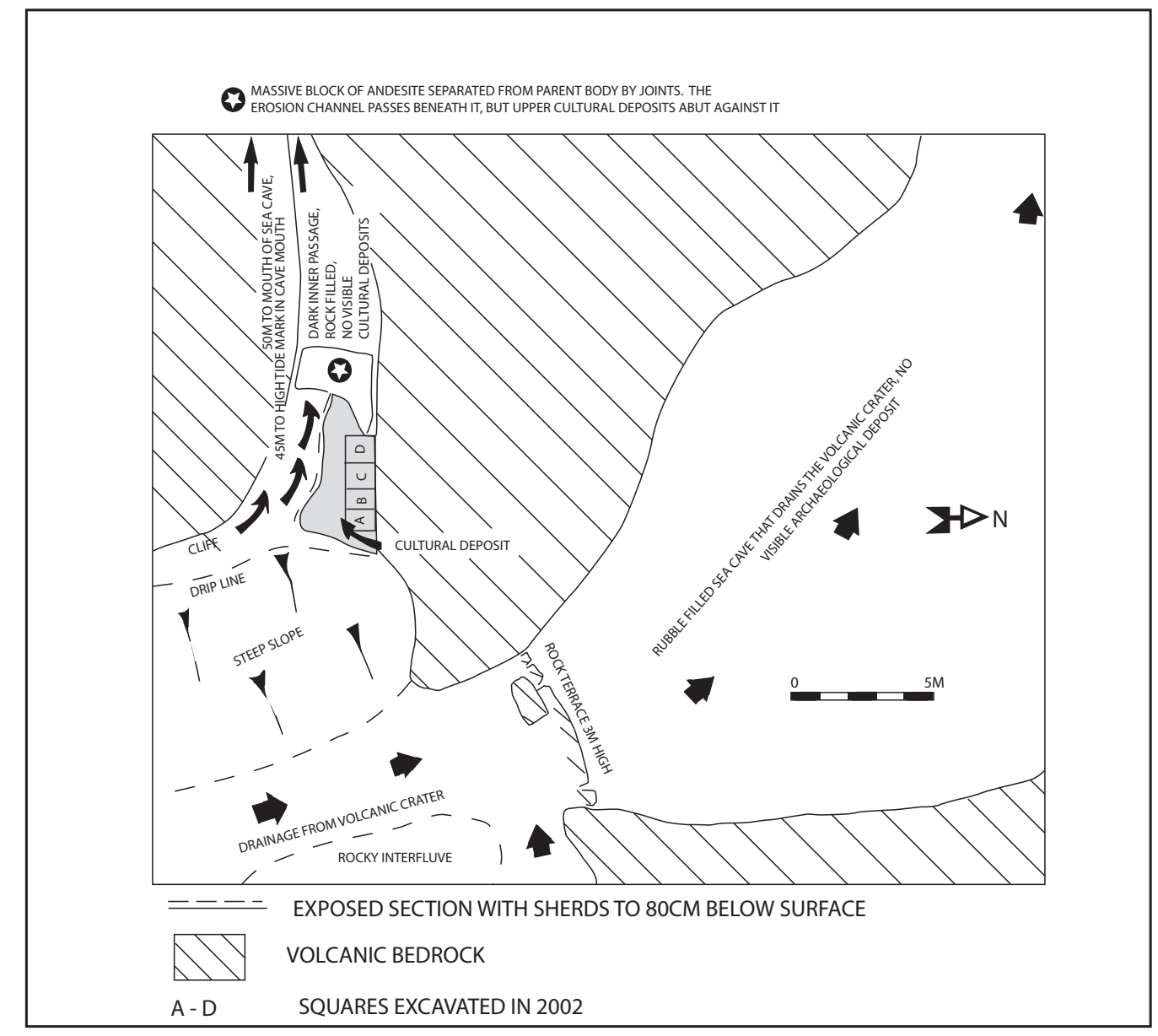

Figure 3.9. Plan of the cave of Mavuyok a Ahchip, with the archaeological deposit in its inland mouth, and the adjacent large open cave which drains the volcanic crater that lies inland. 
Excavation was concentrated in an area of 2.5 by $1 \mathrm{~m}$ against the cave wall. The deposits were neutral ( $\mathrm{pH}$ 6.5-7) and bone and shell preservation was good, even if economic materials turned out to be surprisingly scarce. Five layers were recognised during and after excavation, the top three being ill-defined cultural layers with very diffuse boundaries:

Layer 1: upper cultural layer, $20 \mathrm{~cm}$ thick: dry cave soil with a tripod hearth of three stones and plentiful ash towards the front of the cave.

Layer 2: a relatively clay-rich layer about $20 \mathrm{~cm}$ thick with a similar density of material culture to layer 1 .

Layer 3: a cultural layer with an extremely high density of large sherds, with two side-by-side stone tripod hearths and a dense concentration of volcanic oven stones in the inner part of the cave. At times in this layer, the volume of sherdage seemed to be much greater than the volume of matrix. Much of the deposit was ash and charcoal, and the quantity of residue inside many body sherds left no doubt that this was an area of very intensive cooking.

Layer 4: soft, loose matrix similar to layer 3, but culturally sterile.

Layer 5: culturally-sterile cemented silt with many water-rolled stones, deposited by a former water course. The cave clearly drained the volcanic crater prior to the start of human usage; at present the drainage goes to the sea through the larger cave immediately to the north.

The distribution of sherds shows almost continuous deposition through about $95 \mathrm{~cm}$ of stratigraphy, with slight reductions in quantity between 30 and $50 \mathrm{~cm}$ depth. There are four charcoal C14 dates for the site, all in stratigraphic order and running from "modern" at 5-10 $\mathrm{cm}$ depth down to $900 \pm 60 \mathrm{BP}$ near the base of layer 3 (Table 5.1). In other words, the cave sequence spans the final 600 years or so of Batanes prehistory, prior to the arrival of Dampier and the Spanish missions. It contains no Preceramic or Neolithic assemblages. Indeed, following our excavations in 2002, some treasure hunters found the cave and dug a large pit right down to bedrock, in the process destroying the site for any future research. Examination of the walls of this pit, which was left open (treasure hunters rarely backfill), indicated that no archaeological evidence existed below the excavated layers with pottery.

\section{Dios Dipun Rockshelter}

About $3 \mathrm{~km}$ south of Mahatao, a long ridge extends from the sea into the interior of the island. On the north side, at various points along it, are limestone rockshelters, especially just below the crest of the ridge. A series of these was inspected and the most extensive shelter, Dios Dipun, was selected for excavation in 2002. Dios Dipun encloses about 13 by 4 metres, but unfortunately the floor slopes down longitudinally, a circumstance that has promoted water flow and a tendency for cultural materials to move down to the northern end of the site, where large numbers of recent prehistoric sherds lie on the modern surface.

Only one trench in Dios Dipun produced significant finds. This was TP 2, which had a main excavated area of 2 by $1 \mathrm{~m}$. Pottery, all of an unslipped late prehistoric type similar to that from Mavuyok a Ahchip, occurred sparsely down to $80 \mathrm{~cm}$ and then virtually ceased. On digging deeper, however, a tightly flexed burial with no associated grave goods, other than a few small pieces of red ochre, was encountered at $1.65 \mathrm{~m}$ depth. It was lying in a shallow, seemingly natural depression in the limestone bedrock, and was partly covered, over the cranium, by two large basalt boulders. The edges of the immediate burial pit were quite sharply defined in compact clay. Immediately above, the fill was fairly loose and dry, and included some reddish, weathered pieces of limestone. Above $1.5 \mathrm{~m}$ depth, compact mixed clay and abundant limestone rubble obscured any sign of the grave, so it is not clear from which level it was cut. The burial was sent to the 
National Museum in Manila in 2002, where it was misplaced for a while before being recently found again (2013). We will try to obtain a C14 date on bone from it, but the result will probably arrive too late for publication in this monograph.

Existing radiocarbon dates for Dios Dipun suggest that the bulk of the deposit, except possibly for the burial and its immediate vicinity close to bedrock, is quite recent and badly disturbed. It is possible that the site has suffered from treasure hunting. One $\mathrm{C} 14$ date on charcoal from a depth of $175 \mathrm{~cm}$ is only 500 260 radiocarbon years BP (ANU 11696). Another from $120 \mathrm{~cm}$ is $590 \pm 110$ (ANU 11736). Dios Dipun thus appears to have been occupied during a single and recent phase, and not very intensively. Both Dios Dipun and Mavuyok a Ahchip were originally excavated in the hope that they would yield early pottery and even preceramic assemblages. Neither fulfilled expectations in this regard.

\section{Mavatoy Rockshelter}

We were first shown Mavatoy rockshelter in 2002. At about $8 \mathrm{~m}$ long by $4 \mathrm{~m}$ deep, and 2 metres high in its forward portion, with a few sherds on its flat surface, it seemed to offer the promise of early deposits that we had failed to find in Mavuyok a Ahchip and Dios Dipun. The shelter underlies a large block of limestone that is encased within a massive flow of volcanic agglomerate. In 2003 , a 3 by $1 \mathrm{~m}$ trench was excavated in its central portion (Fig. 3.10). This revealed that volcanic agglomerate forms the bedrock of the shelter and slopes down very steeply into a fairly precipitous external slope that drops to the sea. On the bedrock lies a culturally sterile brown soil (layer 5), thin and fairly patchy. On top of this lies culturally sterile and perhaps primary volcanic ash, layer 4, very similar in colour and texture to the 1500 BP Iraya volcanic ash that covers Sunget and Naidi. Archaeology begins only in layer 3, a redeposited volcanic ash with many small pieces of limestone. In square $\mathrm{A}$, sherds extend down to the base of this layer, but in squares $\mathrm{B}$ and $\mathrm{C}$ they only extend down to about $30 \mathrm{~cm}$ below its top, and the lower portion is culturally sterile. Sherds continue upwards through layers 2 and 1, layer 2 having much charcoal and red burnt soil. The greatest density of sherds occurs between 10 and $25 \mathrm{~cm}$ below the surface in all squares, and all the pottery is of the recent type found at Mavuyok a Ahchip and Dios Dipun, with the exception of one red-slipped sherd of Sunget type and fabric found at the base of the pottery bearing layer. A C14 date on Turbo shell from close to the base of the pottery layer in square A is only $682 \pm 49$ radiocarbon years BP (WK 13090).

Mavatoy, unfortunately, failed like the other Batan rockshelters to produce any pre-eruption cultural materials, in this case because its floor was simply too steep for occupation until a layer of primary or in-washed ash (layer 4) provided a sufficiently level surface. The Batan preceramic, if it exists, still eludes us. Indeed, the whole Batanes Islands preceramic, if it once existed, eludes us as well! 


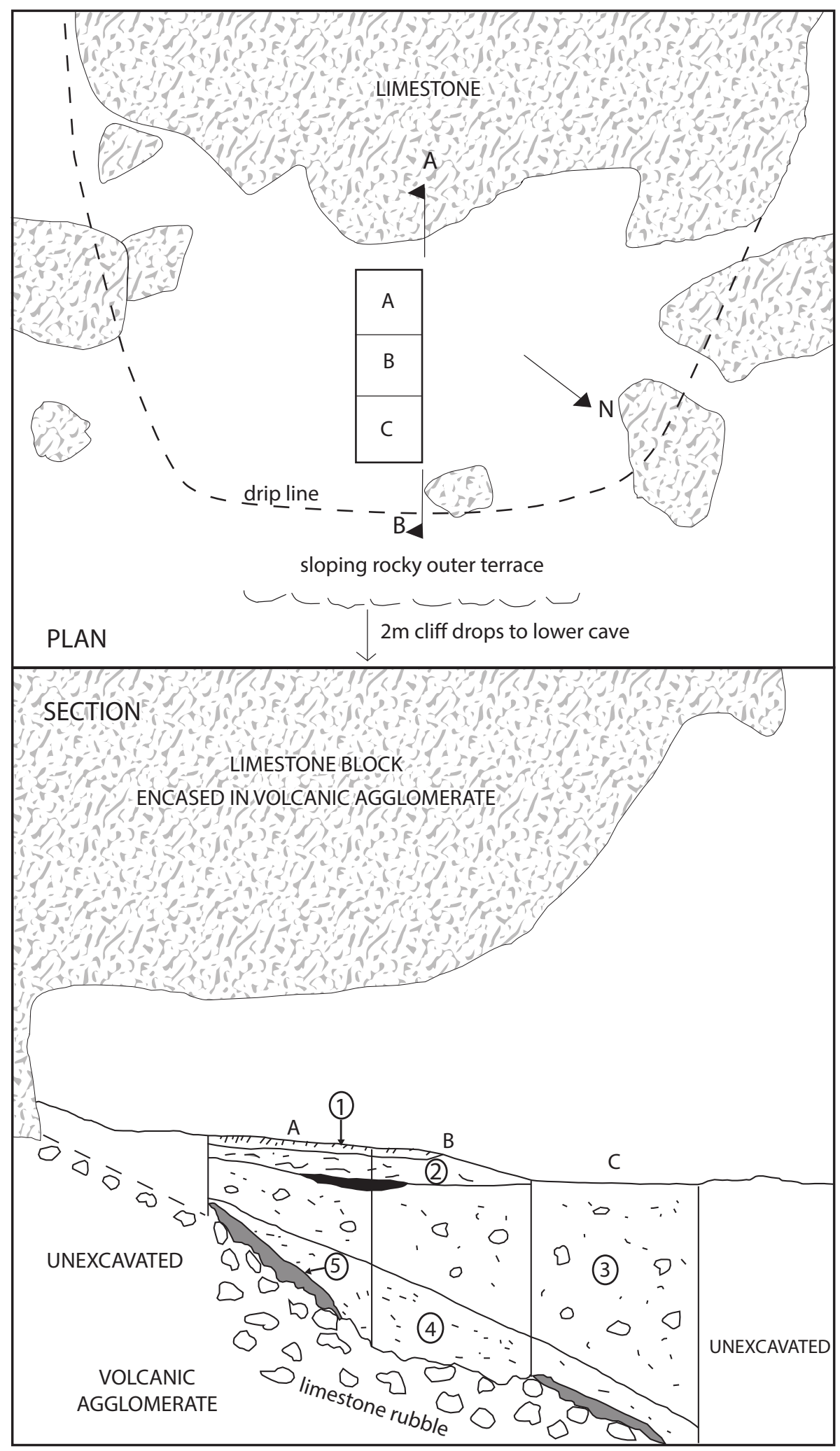

Figure 3.10. Upper: Plan of the Mavatoy rockshelter, showing the excavation trench A-C. Lower: Section of the northern wall of the Mavatoy excavation.

Source: Map preparation by ANU College of Asia and the Pacific, CartoGIS. 